\title{
表面があらい一本の繊維によるふく射の散乱*
}

\author{
牧 野 俊 郎*1, 堀 場 潤 一*2
}

\section{Scattering of Radiation by a Fiber with a Rough Surface}

\author{
Toshiro MAKINO and Jun-ichi HORIBA
}

\begin{abstract}
We present a new theory on the scattering of radiation by real fibers in engineering systems. The theory covers the scattering by fibers consistently over an entire range of fiber sizes, from smaller than to larger than the wavelength of radiation. A geometrical technique is presented for modelling a fiber with a rough surface of $3 \mathrm{D}$-selfsimilar microstructure. Scattering characteristics of the fiber are described based on an electromagnetic wave theory of diffraction, in order to investigate the relationship among three main factors of scattering: wavelength of radiation, fiber diameter and microstructure of the fiber. It is clarified that with an increase in fiber diameter and a corresponding increase in rough fiber surface microstructure, the scattering changes from a particle scattering-type to a surface scattering-type. The transition occurs in the size parameter range of $P=100 \sim 300$.
\end{abstract}

Key Words: Heat Transfer, Thermal Radiation, Thermophysical Property, Spectroscopic Measurement, Scattering, Fiber, Real Surface, Surface Roughness, Fractal

\section{1. 緒}

粒子や繊維からなる非均質媒質における伝熱現象 は，ふく射の散乱特性によって強く特徴づけられる。 また, ふく射散乱の測定は粒子や繊維の大きさや数密 度などを調べるためのよい計測の手段である。そのた め, 粒子や繊維によるふく射の散乱は, 熱工学のふく 射伝熱問題における主要な研究課題の一つになってい る.

この課題に対して, 熱工学は, 理想的な 1 個の球に よる散乱に関する Mie 0理論や理想的な 1 本の円柱 による散乱に関する Maxwell 方程式の解(1) 基礎と して, 実在の粒子群や繊維層の性質を計算してきた。 この場合, 粒子や繊維の数密度が小さいとき, その性 質は, 粒子や瀻維の直径とふく射の波長の関係を表す サイズパラメータだけで特徵づけられた。

この方法は, しかし, 粒子や繊維の大きさがふく射 の波長程度以下のものである場合にのみ正当である. 熱工学が対象とする工学系では, 多くの場合, 粒子や

* 1996 年 5 月 16 日 第 33 回日本伝熱シンポジウムにおいて 講演, 原稿受付 1996 年 12 月 5 日.

*1 让員, 㝠都大学大学院工学研究科（更606-01 京都市左京区 望田本町)

*2 学生貪, 京都大学大学院.
繊維は電磁波理論が想定するサイズに比べて大きく, その表面には粒子や繊維の大きさに応じて大きい表面 あらさがあるからである。例えば，球形粒子が，すす 粒子・砂じん・サッカーボール・月，‥のように大き くなり, 円柱が, 繊維・毛髪・伝熱管・樹木, ‥のよ うに太くなるとき，その散乱特性が単純な形状の粒子 や繊維についてたてた電磁方程式の理論解に近くない ことは，容易に推察できる，粒子が大きいとき，ふく 射の散乱は粒子散乱のみならず粒子表面の散乱の様式 によって強く特徵づけられるであろう。

これまでには，大きい粒子による散乱を扱うのに， 幾何光学的な方法(2) が採られることもあった.この 場合, 粒子の表面に扔けるふく射散乱は完全拡散反射 あるいは鏡面反射的のいずれかであると仮定された。 この方法は，しかし，実用的にも便利ではない。とい うのは，実在表面の反射は一般にいくぶん鏡面反射的 かつ拡散反射的であり，また，その仮定の選択の影響 は大きいからである。

熱工学の目的のためには, 粒子や繊維が小さい場合 から大きい場合にまでわたって，ふく射散乱を統一的 に扱える理論が提案され，粒子散乱と表面散乱が同一 の基礎上で扱われることが望ましい．著者らの一人 は, 表面があらい薄板状粒子のモデル化手法を提案し, 
その散乱特性を調べた ${ }^{(3)}$. その結果, このような粒子 の散乱は, ふく射の波長, 粒子の直径, 表面の微視構 造の三者の関係で特徵づけられ, 粒子の大きさの増加 とともに, 粒子散乱的なものから表面散乱的なものに 移行することが示された。

本研究では，この研究の考え方を表面があらい瀻維 のふく射散乱特性の研究に拡張する. 表面に自己相似 的なあらさのある瀻維をモデル化する手法を提案し， 繊維が太くなるとその散乱特性は理想的な円柱のそれ から外れることを明らかにする。

\section{記 号}

$2 a:$ 繊維の直径 $\mathrm{m}$

$2 a \Delta \theta$ : 繊維の表面構造の円周方向の最小値の代表サ イズ $\mathrm{m}$

$\hat{\boldsymbol{E}}:$ 電磁波の複素電場ベクトル $\mathrm{V} \cdot \mathrm{m}^{-1}$

$E_{l}:$ 電磁波の複素電場の $l=(=X, Y, Z)$ 成分 $\mathrm{V} \cdot \mathrm{m}^{-1}$

$\widehat{g}:$ 式 $(9)$ で定義される複素関数 $\mathrm{V} \cdot \mathrm{m}^{-3}$

$h^{*}:$ 繊維の表面要素の傾きの代表值

$I:$ ふく射の相対強度

$i:$ 虚数単位

$j:$ 自己相似化過程の第 $j$ 段階

$j_{\max }$ : 自己相似化過程の最終段階

$k:$ 電磁波の波数 $\mathrm{m}^{-1}$

$l:$ 繊維の長さ $\mathrm{m}$

$M:$ 瀻維ユニット作成過程で並べる成分面の数

$\boldsymbol{m}_{i}:$ 瀻維表面の第 $i$ 番めの要素の法線方向単位べ クトル

$\left(m_{j}, n_{j}\right):$ 第 $j$ 投影面上の斜交座標

$N$ : 瀻維モデル作成過程で並べる瀻維ユニットの 数

$N$ : 繊維表面の半径方向の単位ベクトル

$\bar{n}:$ 纎維を構成する物質の光学定数

$P:$ 繊維のサイズパラメータ

$p:$ 瀻維表面の微視構造のサイズパラメータ

$\boldsymbol{R}:$ 観測点の位置ベクトル $\mathrm{m}$

$r:$ 位置ベクトル $\mathrm{m}$

$r^{\prime}$ : 絨維の表面要素上の点の位置ベクトル $\mathrm{m}$

$S^{\prime}$ : 瀻維の表面要素の表面の面積 $\mathrm{m}^{2}$

$2 x_{0}$ : 第 1 投影面上の表面要素の一辺の長さ, 絨維 の表面構造の円周方向の最大值の代表サイズ $\mathrm{m}$

$x, y, z$ : あらい表面の構造のための座標 $\mathrm{m}$

$X, Y, Z$ : 緘維によるふく射散乱系のための座標 $\mathrm{m}$

$z_{0}$ : 基準高さ, 纎維の表面構造の高さ方向の最大
值の代表サイズ $\mathrm{m}$

$\alpha:$ 自己相似化のパラメータ, $0<\alpha<1$

$\alpha^{j \max -1} z_{0}$ : 䋐維の表面構造の高さ方向の最小值の代表

サイズ $\mathrm{m}$

$\theta, \phi:$ 図 4 に定義する散乱の方位角と天頂角

$\lambda$ : 真空中での電磁波 (ふく射)の波長 $\mathrm{m}$

$\Sigma: \mathrm{rms}$ あら $\mathrm{m}$

$\tau:$ 自己相関長さ $\mathrm{m}$

$\hat{\psi}:$ 式(10)で定義される複素関数 $\mathrm{m}^{-1}$

(太文字)：ベクトル量

\section{: 複素量}

\|\|$:$ 複素ベクトル量のノルム

添 字

$i:$ 繊維表面の第 $i$ 番めの表面要素

in: 入射波

$j:$ 自己相似化過程の第 $j$ 段階

scat：散乱波

specular：表面が滑らかな繊維

rough：表面があらい瀻維

\section{2. 表面があらい䌜維のモデル}

本研究で提案する, 表面があらい繊維のモデルは, 表面に自己相似的な三次元凹凸構造をもつものであ る. そのモデル作成のアルゴリズムは, 著者の一人が さきに提案した三次元重ね合わせ法 ${ }^{(4)}$ の考え方を基 礎とする. そのモデルでは, 繊維が太く, それに応じ て表面の山凸構造も大きい表面には，そこに入射する ふく射と同じ程度の構造があることになる。

図 1 に示すように, $x-y$ 平面上に一辺の長さが $2 x_{0}$ である二つの正三角形からなる菱形の領域を設ける. この菱形の領域を $j_{\max }$ 個だけ準備する.この菱形の 各辺を $3^{j}$ 等分 $\left(j=1,2, \cdots, j_{\max }\right) し, 2 \cdot 3^{2 j}$ 個の小三角 形を得る。この小三角形からなる平面図形(第 $j$ 投影 面)上の小三角形の○, ・ ○印の頂点 $\left(m_{j}, n_{j}\right)$ から $z$ 方向に長さが $\alpha^{j-1} z_{0}$, 向きがそれぞれ負, 零, 正のべ クトルを生成する， $z_{0}$ は基準高さ， $\alpha$ は自己相似化の パラメータであり, $0<\alpha<1$ である. 各ベクトルの終 点を最近接のべクトルの終点と結び, 網目構造,

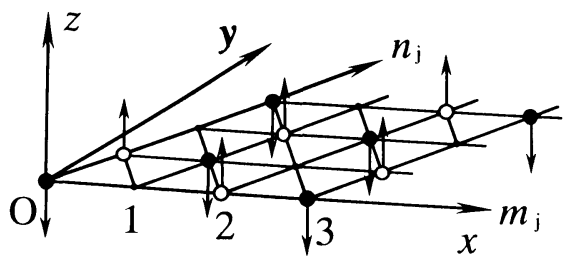

Fig. 1 1st projection plane $(j=1)$ 


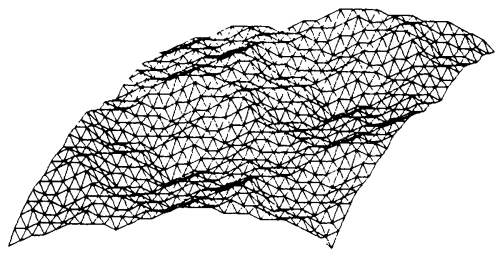

Fig. 2 Appearence of surface microstructure $\left(j_{\max }=3\right)$

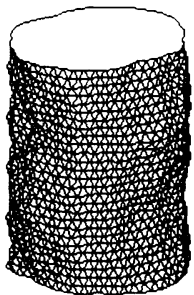

Fig. 3 Appearence of fiber unit $\left(j_{\max }=3, M=2\right)$

$$
z_{j}=z_{j}(x, y)
$$

を構成する.この構造を第 $j$ 成分面と呼ぶ. $j=1,2$, $\cdots, j_{\max }$ の $j_{\max }$ 個の成分面を得て, これらを $z$ 方向に 重ね合わせ, 一つの構造,

$$
z(x, y)=\sum_{j=1}^{j \max } z_{j}
$$

を作成する(図 2).この構造を $x$ 方向に $M$ 個並べ, 円柱状に丸めて繊維ユニットを作る(図 3), ここで, このユニット表面の網目構造を構成する多数の小三角 形(表面要素) は平面三角形であり，そのユニットは中 実のものであると考える.そのユニットを円柱の軸方 向に $N$ 個だけ積み上げ, 直径が $2 a\left(=2 x_{0} M\right)$, 長さが $l\left(=3^{1 / 2} \pi a N / M\right)$ の繊維モデルを作る。かくして, $j_{\max }$ が大きい場合, 自己相似的な表面の山凸構造をもつ繊 維の三次元モデルが完成する.

このようにして作成された繊維モデル表面の幾何構 造は，その大きさによらず，たがいに完全に相似的で ある。また，このモデルは，その作成過程に確率操作 を含まないので一意的に指定される，以下では，この 繊維のモデルを繊維と呼ぶ。

\section{3. 電磁波の散乱}

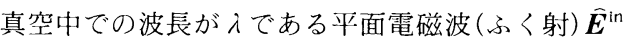
が, 真空中にある繊維に, その軸に垂直な $X$ 方向か ら入射するときの散乱特性を調べる。図 4 は，この状 況を表す。繊維上の各表面要素(最小の三角形要素)の 表面上に形成される複素電場を計算し, その電場が繊 維から遠方の観測点 $\boldsymbol{R}$ に形成する回折波の合成電場

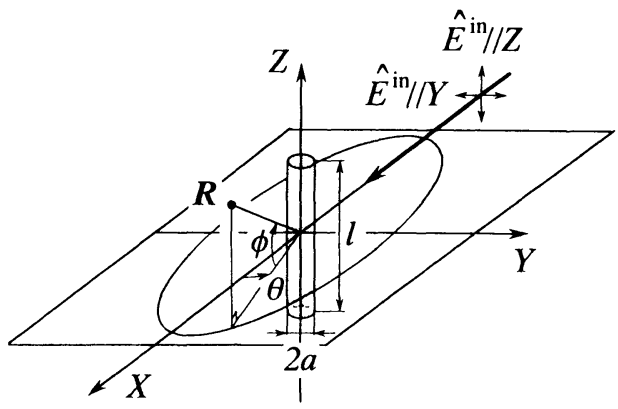

Fig. 4 Coordinate system for radiation scat tering description

を Kirchhoff 理論に基づいて計算する。ここで，次の ( 1 ) 〜 ( 3 ) を仮定する.

（1）表面要素の表面の各点の電場は，その点にお ける入射電場と Fresnel の反射則により表される反射 電場からなる。

（2）回折波の電場については, Fraunhofer 近似 が成立する。

（3）複数の表面要素での回折波の間での多重回折 は生じない。

位置 $\boldsymbol{r}$ における全電場 $\widehat{\boldsymbol{E}}(\boldsymbol{r})$ は, 一般に, 位置 $\boldsymbol{r} に$ 入射する一次的な電場 $\hat{\boldsymbol{E}}^{\mathrm{in}}(\boldsymbol{r})$ と散乱・反射などの変 換を経た二次的な電場 $\hat{\boldsymbol{E}}^{\mathrm{scat}}(\boldsymbol{r})$ の合成電場として，次 式で表される。

$$
\widehat{\boldsymbol{E}}(\boldsymbol{r})=\hat{\boldsymbol{E}}^{\mathrm{in}}(\boldsymbol{r})+\hat{\boldsymbol{E}}^{\mathrm{scat}}(\boldsymbol{r})
$$

同様に, 表面要素の表面の位置 $\boldsymbol{r}^{\prime} に$ にるる全電場 $\widehat{\boldsymbol{E}}\left(\boldsymbol{r}^{\prime}\right)$ は

$$
\widehat{\boldsymbol{E}}\left(\boldsymbol{r}^{\prime}\right)=\widehat{\boldsymbol{E}}^{\text {in }}\left(\boldsymbol{r}^{\prime}\right)+\widehat{\boldsymbol{E}}^{\text {scat }}\left(\boldsymbol{r}^{\prime}\right)
$$

であり，観測点 $\boldsymbol{R}$ における全電場 $\widehat{\boldsymbol{E}}(\boldsymbol{R})$ は,

$$
\widehat{E}(\boldsymbol{R})=\widehat{\boldsymbol{E}}^{\mathrm{in}}(\boldsymbol{R})+\hat{\boldsymbol{E}}^{\mathrm{scat}}(\boldsymbol{R})
$$

である。この散乱電場 $\widehat{\boldsymbol{E}}^{\mathrm{scat}}(\boldsymbol{R})$ は，その $l(=X, Y, Z)$ 成分について次式で表される(5)。

$$
\begin{aligned}
\hat{E}_{l}^{\text {scat }} & (\boldsymbol{R})=\hat{E}_{l}(\boldsymbol{R})-\widehat{E}_{l}^{\text {in }}(\boldsymbol{R}) \cdots \cdots \cdots \\
= & \sum_{i}\left[\int_{\text {element }}\left[\widehat{g}_{i}\left\{\widehat{E}_{l}\left(\boldsymbol{r}^{\prime}\right)\right\}\right] d S^{\prime}\right] \cdots \\
= & \sum_{l}\left[\int_{\text {element }}\left[\hat{g}_{i}\left\{\widehat{E}_{l}^{\text {in }}\left(\boldsymbol{r}^{\prime}\right)\right\}\right] d S^{\prime}\right] \\
+ & \sum_{l}\left[\int_{\text {element }}\left[\hat{g}_{i}\left\{\hat{E}_{l}^{\text {scat }}\left(\boldsymbol{r}^{\prime}\right)\right\}\right] d S^{\prime}\right]
\end{aligned}
$$

ここで,

$$
\begin{aligned}
& \widehat{g}_{2}\left\{\widehat{E}_{l}\left(\boldsymbol{r}^{\prime}\right)\right\}=\left[\widehat{E}_{l}\left(\boldsymbol{r}^{\prime}\right)\left\{\boldsymbol{m}_{i} \cdot \nabla \hat{\psi}(\boldsymbol{R})\right\}\right. \\
& \left.-\widehat{\psi}(\boldsymbol{R})\left\{\boldsymbol{m}_{t} \cdot \nabla \hat{E}_{1}\left(\boldsymbol{r}^{\prime}\right)\right\}\right] /\left(4 \pi \boldsymbol{N} \cdot \boldsymbol{m}_{i}\right) \\
& \bar{\psi}(\boldsymbol{R})=(1 /|\boldsymbol{R}|) \exp (i k|\boldsymbol{R}|)
\end{aligned}
$$

である。ただし， $\boldsymbol{N}$ は繊維の半径方向の単位べクトル 
であり, $k$ は真空中での電磁波の波数 $(=2 \pi / \lambda)$ であ る. 積分 $\int_{\text {element }}[\cdots] d S^{\prime}$ は緎維の各表面要素の表面に わたって，加算 $\sum_{i}$ は繊維のすべての表面要素にわた つて行う. 式 (8)の第 1 項は繊維への入射電場 [式 (4)第 1 項] の散乱電場への寄与を表し, 第 2 項は粒 子の表面要素での反射を経た電場 [式(4)第 2 項］の 散乱電場への寄与を表す。すべての表面要素での回折 波の観測点 $\boldsymbol{R}$ における散乱電場 $\hat{\boldsymbol{E}}^{\mathrm{scat}}(\boldsymbol{R})$ は, この 2 種の電場の寄与の合成複素電場として表される.

繊維には自然光が入射するものとし,たがいに垂直 に偏光する 2 種の直線偏光入射波の強度に対する散乱 波の相対強度,

$$
\left\|\hat{\boldsymbol{E}}^{\text {scat }}(\boldsymbol{R})\right\|^{2} /\left\|\hat{\boldsymbol{E}}^{\mathrm{in}}(\boldsymbol{0})\right\|^{2}
$$

を求め, その結果を両偏光について単純平均する.こ こで, 演算記号 \|\| は複素ベクトル量のノルムを表 す.さらに，その平均值を図 4 に定義する散乱の方位 角 $\theta$ または天頂角 $\phi$ について移動平均し, 相対散乱 強度 $I^{\text {scat }}(\phi, \theta)$ の分布を求める。この移動平均は, 表面の微視構造によるふく射干涉の結果として現れる 散乱強度分布の空間構造(スペックル)をまるめるため のものである.

\section{4. 数 値 計 算}

以上の理論において繊維によるふく射散乱特性は, ふく射の波長 $\lambda$ と繊維の直径 $2 a$ ならびに繊維表面の 微視構造に依存する。いま，繊維とその表面の微視構 造のサイズパラメー夕を，それぞれ，

$$
P=2 \pi a / \lambda, p=2 \pi a \Delta \theta / \lambda
$$

と定義する. $2 a \Delta \theta$ は繊維の表面要素の一辺の長さで ある. 繊維の散乱特性を特徵づける入力パラメータ は, $P, l, \alpha, j_{\max }, M$ と繊維の表面要素の傾きの代表值,

$$
h^{*}=z_{0} /\left(3^{j \max -1} \cdot 2 a \Delta \theta\right)
$$

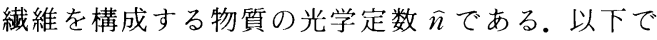
は,

$P=3,30,90,300,3000$

の 5 種の繊維の散乱特性を調べる。ここで， 5 種の繊
維にわたって共通に,

$$
\begin{aligned}
& l=3.0 \mathrm{~mm}, \quad \alpha=1 / 3, \quad j_{\max }=5, M=10, \\
& h^{*}=1 / 30, \hat{n}=3+4 i, \lambda=1 \mu \mathrm{m} \cdots \cdots \cdots
\end{aligned}
$$

であるとする.この光学定数 $\hat{n}$ の值は, ふく射を透 過しない金属的な特性をもつ繊維を想定するものであ る.繊維はふく射の波長 $\lambda$ に比べて十分に長い. 観 測点 $\boldsymbol{R}$ は $|\boldsymbol{R}|=10 \mathrm{~m}$ の球面上にあるとする.

表 1 にこれらの 5 種の繊維の諸元を示す。これらの 繊維は, $1180980\left(=2 \cdot 3^{2 j \max } M\right)$ 個の表面要素からな る繊維ユニットを, 繊維軸の方向に, $P=3 \sim 3000$ の 繊維についてそれぞれ $N=11548,1156,386,116$, 12 個連結したものである.この 5 種の緎維の表面の 幾何構造はたがいに完全に相似的である。その断面プ ロファイルのフラクタル次元は 1.1 である.

表 1 で, $2 a$ と $l$ は，それぞれ繊維の直径と長さであ り, 纎維の概形を表す。 $\tau$ と $\Sigma$ は, それぞれ繊維の表 面の断面プロファイルの自己相関長さと平方根平均二 乗 $(\mathrm{rms})$ あらさである. $2 x_{0}$ と $z_{0}$ は, それぞれ繊維の 表面構造の円周方向と半径方向(高さ方向)の最大值の 代表サイズである． $2 a \Delta \theta$ と $\alpha^{j \max -1} z_{0}$ は，それぞれ繊 維の表面構造の円周方向と半径方向の最小値の代表サ イズである. 仮定 $(3)$ に関連して, 表面の三角形要素 の平均傾きは $5.02^{\circ}$, 最大傾きは $18.4^{\circ}$ である.

ここで, 本研究の繊維の散乱の理論は, 基本的に, 式(11)に与える $P$ と $p$ を変数として記述されるので, $\lambda$ と繊維の直径・表面の微視形状の大きさの関係が同 一である系でのふく射散乱は， $\hat{n} の$ 波長依存性が強く ないとき, 完全に同様に起こる.

\section{5. 計算結果および考察}

5・1 計算結果 図 5 9 に計算結果を示す。これ らの図では, 円周方向に, 散乱の方位角 $\theta$ あるいは天 頂角 $\phi$ を, 半径方向の対数軸上に散乱強度 $I^{\text {scat }}(\phi, \theta)$ をとって, 散乱のオーダ的な特性に注目する。ふくく射 は繊維の軸に垂直な $(\theta, \phi)=\left(0^{\circ}, 0^{\circ}\right)$ の方向に入射す

\begin{tabular}{|c|c|c|c|c|c|c|c|c|c|}
\hline & $P$ & $\begin{array}{l}2 a \\
\mu \mathrm{m}\end{array}$ & $\begin{array}{l}l \\
\mathrm{~mm}\end{array}$ & $\begin{array}{l}\tau \\
\mu \mathrm{m}\end{array}$ & $\begin{array}{c}\Sigma \\
\mu \mathrm{m}\end{array}$ & $\begin{array}{l}2 x_{0} \\
\mu \mathrm{m}\end{array}$ & $\begin{array}{l}z_{0} \\
\mu \mathrm{m}\end{array}$ & $\begin{array}{c}2 a \Delta \theta \\
\mu \mathrm{m}\end{array}$ & $\alpha_{\mu \mathrm{m}}^{j \max -1} z_{0}$ \\
\hline & 3 & 0.955 & 3 & 0.0359 & 0.00144 & 0.300 & 0.00333 & 0.00123 & 0.0000137 \\
\hline & 30 & 9.55 & 3 & 0.359 & 0.0144 & 3.00 & 0.0333 & 0.0123 & 0.000137 \\
\hline & 90 & 28.7 & 3 & 1.08 & 0.0433 & 9.00 & 0.100 & 0.0370 & 0.000412 \\
\hline & 300 & 95.5 & 3 & 3.59 & 0.144 & 30.0 & 0.333 & 0.123 & 0.00137 \\
\hline 3 & 000 & 955 & 3 & 35.9 & 1.44 & 300 & 3.33 & 1.23 & 0.0137 \\
\hline
\end{tabular}
る.ふく射の波長を固定して考えると, 繊維の直径は 図( a ), ( b )，，（e ）の順に大きくなる.

Table 1 Specification of modelled fibers with rough surfaces of $h^{*}=1 / 30$ (for radiation of $\lambda=1.0 \mu \mathrm{m}$ ) 
$5 \cdot 2$ 解析解と数値解 図 5,6 は, 表面が滑らか な繊維の軸に垂直な $\phi=0^{\circ}$ の面の方向への散乱強度 $I^{\text {scat }}\left(0^{\circ}, \theta\right)$ の特性を表す. 図 5 は, 表面が滑らかで無 限に長い理想的な円柱の特性を Maxwell 方程式の解 析解に基づいて計算したものである. その計算の過程 における Bessel 関数と Neumann 関数の計算には, 両関数の Hankel 漸近展開式と両関数が満足する漸化 式を用いた。図 6 は，本研究のモデルで表面がもっと も滑らかな $h^{*}=0$ の繊維について数値解を示す。こ れらの繊維の表面は表面要素からなるので,これらの 繊維は厳密な意味で円柱ではないが, ふく射の波長を $\lambda=1 \mu \mathrm{m}$ とするとき, その凹凸は $\Sigma<1 \mathrm{~nm}$ の程度で ある. 図 5,60特性は定量的にもたがいに近い, すな わち, 仮定 (1)，（2）に基づく本計算の結果はこれら の仮定に影響されない.そこで, $5 \cdot 3$ 節以下では, 表 面があらい瀻維の特性(数値解) を図 6 の特性(数值解) と比較し, 表面があらい繊維の特性を論じる.

$P$ が大きい繊維の場合, 散乱は $(\theta, \phi)=\left(0^{\circ}, 0^{\circ}\right)$ の 前方で極めて強いが, これは散乱を扱う研究が, 式
（5）の全電場 $\hat{\boldsymbol{E}}(\boldsymbol{R})$ ではなく，散乱電場 $\hat{\boldsymbol{E}}^{\mathrm{scat}}(\boldsymbol{R})$ に 注目することによる．繊維が極限的に大きいとき，そ の繊維の陰の方向にある点 $\boldsymbol{R}$ の電場は, $\hat{\boldsymbol{E}}(\boldsymbol{R})=\mathbf{0}$ あり, 式（５）によれば,

$$
\hat{\boldsymbol{E}}^{\text {scat }}(\boldsymbol{R})=-\hat{\boldsymbol{E}}^{\mathrm{in}}(\boldsymbol{R})
$$

である。すなわち，散乱電場は，入射電場と強度が同

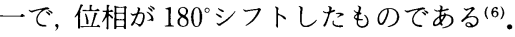

$5 \cdot 3$ 表面があらい纎維の散乱 図 5,6 の表面が 滑らかな繊維の場合, 散乱は, 繊維の軸に垂直な $\phi=$ $0 \circ$ の面 (以下では散乱面と呼ぶ) の方向でいちじるしく 強い. それ以外の方向への散乱は数オーダ弱い. 図 7 は，表面があらい $h^{*}=1 / 30$ の繊維の $I^{\text {scat }}\left(0^{\circ}, \theta\right)$ 特性 を示す.図 6 と図 7 を比較すると, $P<30$ の細い繊維 では, 特性の差異は小さい. 一方, 直径が大きくそれ に伴って表面の山凸が大きい $P>300$ の繊維では，表 面の微視構造の影響が顕著に現れる。すなわち，散乱 面内の方向について大ざっぱにいえば，表面があらい 繊維の場合 (図 7)には, $\theta=0^{\circ}$ の方向以外への散乱ふく 射の強度が, 表面が滑らかな繊維の場合(図 6)に比べ

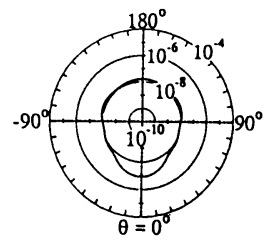

(a) $\quad P=3$

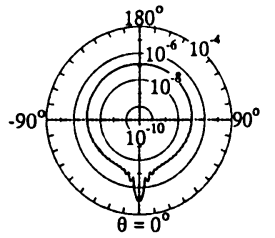

(b) $\quad P=30$

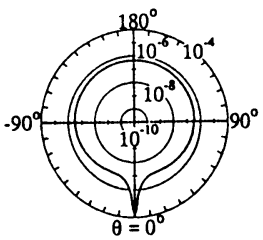

(c) $\quad P=90$

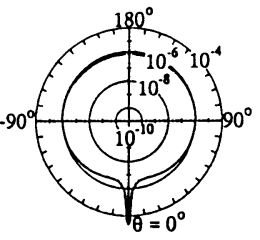

(d) $\quad P=300$

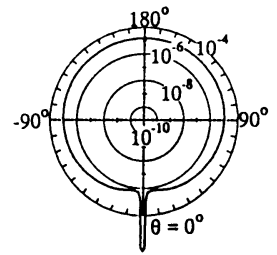

(e) $\quad P=3000$

Fig. $5 I^{\text {scat }}\left(0^{\circ}, \theta\right)$ characteristics of specular fibers (analytical solution)

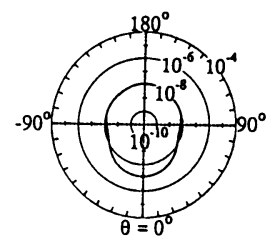

(a) $\quad P=3$

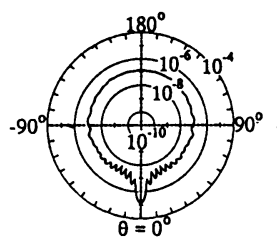

(b) $\quad P=30$

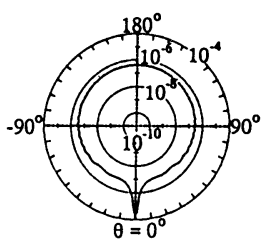

(c) $\quad P=90$

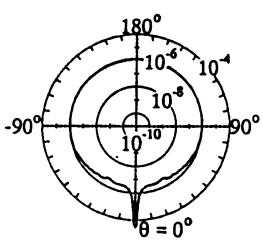

(d) $\quad P=300$

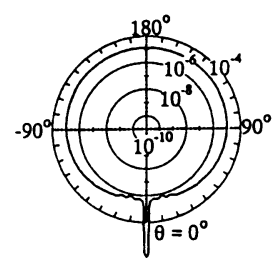

(e) $\quad P=3000$

Fig. $6 I^{\text {scat }}\left(0^{\circ}, \theta\right)$ characteristics of specular fibers of $h^{*}=0$

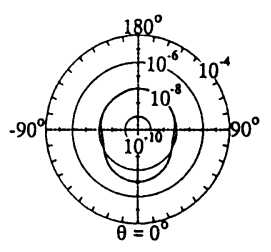

(a) $P=3$

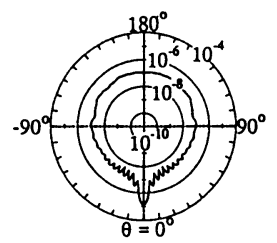

(b) $\quad P=30$

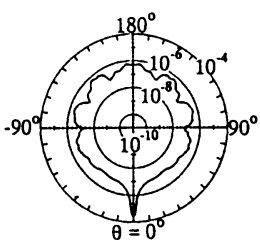

(c) $\quad P=90$

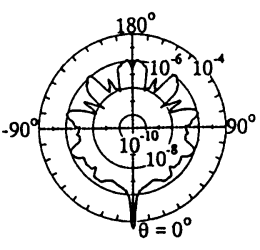

(d) $\quad P=300$

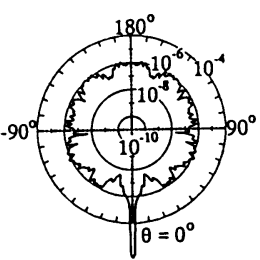

(e) $\quad P=3000$

Fig. $7 \quad I^{\text {scat }}\left(0^{\circ}, \theta\right)$ characteristics of rough fibers of $h^{*}=1 / 30$ 
て $1 / 10 \sim 1 / 100$ の程度に弱い. なお，本研究の表面が あらい繊維の表面の微視形状は, 厳密にいうと, 入射 電場について対称ではないが, 図 6,7 の左右対称性か らのずれは実質的に無視できる.

図 8,9 は, 表面の微視構造の影響がもっとも顕著で ある $P=3000$ の繊維について, 表面があらい $h^{*}=$ $1 / 30$ の繊維の散乱の $\phi$ 方向特性を表面が滑らかな $h^{*}$ $=0$ の繊維の特性と比較するものである。これらの図 は, $I(\theta, \phi)$ 曲面の $\theta$ または $\left(\theta \pm 180^{\circ}\right)$ が一定の一つ づきの断面の左右の部分を表す．表面があらい繊維の 散乱強度は，繊維への入射波の寄与が支配的な $(\theta, \phi)$ $=\left(0^{\circ}, 0^{\circ}\right)$ の前方では表面が滑らかな繊維の場合と実 質的に相等しいが, それ以外のすべての方向では，表 面が滑らかな繊維の場合に比べてはるかに強い。

$5 \cdot 4$ 表面散乱支配の $P$ 領域 表面があらく太い 繊維の上記の特性は, 繊維表面の微視構造による回折 波の干涉現象に起因する。図 10 はこの点を検討する ものである，横軸は $P$ であり，縦軸には，表面があら い瀻維による $(\theta, \phi)=\left(180^{\circ}, 0^{\circ}\right)$ の後方への散乱強度 の, 表面が滑らかな繊維によるその方向への散乱強度 に対する比 $I_{\text {rough }} / I_{\text {specular }}$ を採る。ここで, ○印 (isotropic) は, 表面があらい $h^{*}=1 / 30$ の繊維につい てのものである. 表面の微視構造の影響は $P=100$ を 越えると強く現れ始める。ここで, 繊維(あるいは粒 子)の代表直径だけが散乱の挙動を特徵づける場合に その散乱を ‘粒子散乱’ と呼び, 繊維(あるいは粒子) の表面の微視形状がおもに散乱の挙動を特徵づける場 合にその散乱を“表面散乱’と呼ぶことにすると, 図 10

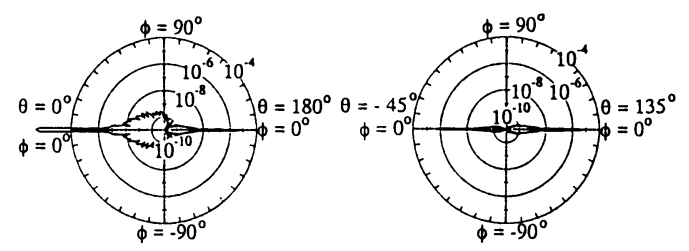

Fig. $8 I^{\text {scat }}\left(\phi, 0^{\circ}\right)$ characteristics of specular fibers of $h^{*}=0$

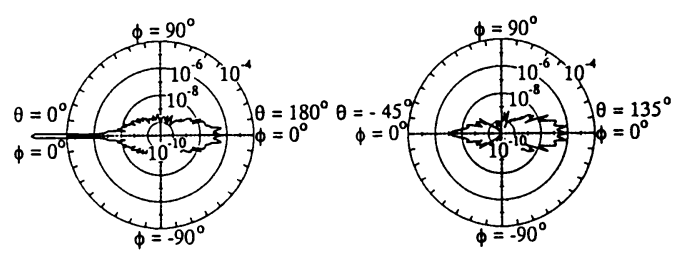

Fig. $9 I^{\text {scat }}\left(\phi,-45^{\circ}\right)$ characteristics of rough fibers of $h^{*}=1 / 30$
からは, $P=300$ では, $I_{\text {rough }} / I_{\text {specular }}$ はすでに表面散 乱的になって一定値をとりつつあるといえる。この散 乱特性の粒子散乱的から表面散乱的への遷移は, 波長 $\lambda=1 \mu \mathrm{m}$ のくく射についていえば, 繊維の直径が

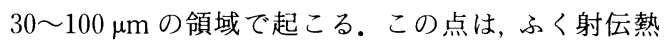
の評価において, またふく射散乱に注目する計測にお いて重要である。

$5 \cdot 5$ 繊維表面の構造の非等方性と散乱特性 実 在の繊維の表面の微視構造は, 必ずしも, 本研究の繊 維におけるように等方的ではない.ここでは, 表面の いかなる構造が上述の特性に強い影響を与えるのかを 検討する.図 10 の○印と口印は，その繊維を構成す る表面要素のうち, それぞれ, 繊維の円周方向に並ぶ 1 行分と軸方向に並ぶ 1 列分による散乱ふく射につい て計算した $I_{\text {rough }} / I_{\text {specular }}$ の値である.

表面が滑らかな繊維の場合には, 繊維表面の繊維軸 方向に並ぶ列の部分での回折波の位相が揃い, 回折波 は繊維軸に垂直な散乱面内でたがいに強め合う。その 面以外の方向ではこの回折波の強め合う干涉は生じに くい,ところが, 表面があらい瀻維で, 繊維表面の繊 維軸方向に並ぶ列の高さが不揃いの部分での回折波 が, 散乱面内で強め合う干涉を生む確率が低く散乱強 度は弱い. 同時に, 散乱面外の方向でも, 強め合う干 涉を生むいくぶんの確率が生じ, $\phi \neq 0^{\circ}$ の方向での散 乱強度は, 表面が滑らかな繊維の場合に比べて強くな る. 一方, 繊維表面の円周方向に並ぶ行の部分での回 折波の位相は，理想的な円柱の場合でも， $(\theta, \phi)$ のい かなる方向においても揃うことがないので，その部分 からの散乱のふるまいは, 表面が滑らかな繊維でも表 面があらい繊維でも，実質的に同様である．以上のこ とがらを象徵的にいえば,リーマ状の緎維の散乱特性 は滑らかな繊維のものに近く, ボルト状の繊維の散乱 特性はその山凸の強い影響を受けることになる。

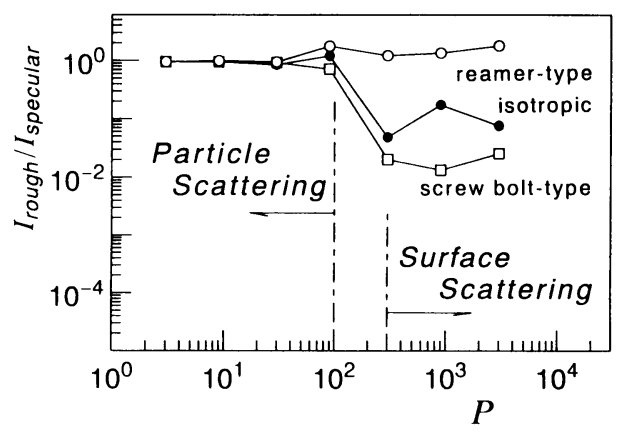

Fig. 10 Size parameter ranges of particle scattering and surface scattering 


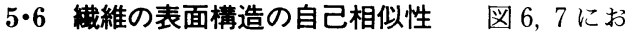
いて, $P \leqq 90$ の細い繊維では, 散乱特性は繊維表面の 微視構造の影響を受けない.すなわち, $P \leqq 90$ の繊維 の表面の高さ方向の最大值の代表サイズが $z_{0} \leqq 0.1 \mu \mathrm{m}$ である構造(表 1)は, $\lambda=1 \mu \mathrm{m}$ のふく射に対する散乱 特性に影響を及ぼさない.一方，もっとも太い $P=$ 3000 のく射でも，その表面には高さ方向の最小值の 代表サイズが $\alpha^{j \max -1} z_{0} \sim 0.01 \mu \mathrm{m}$ の詳細構造がある. したがって, 本研究のもっとも太い繊維でも，その表 面には実質的に自己相似的な微視構造があることにな る.

散乱強度は, 式 ( 8 )に示すように, 繊維への入射電 場の寄与 [式 ( 8 )右辺第 1 項］と繊維の表面での反射 を経た電場の寄与(第 2 項)を重ね合わせた合成複素電 場の強度で表される。この点に関係して, 山田・黒 崎 ${ }^{(7)}$ は, 理想的な円柱について, その直径が大きい場 合には, 散乱強度が第 1 項の電場の強度と第 2 項の電 場の強度の単純和として表せることを示したが，この 加算性は, 本研究の表面があらい繊維についても $P=$ 10〜3000の範囲で成立することがわかった。ただし， この点は, 計算以前に推定されたことである。すなわ ち，第 2 項の電場についていえば，理想的な円柱の表 面の部分部分での反射を経た電場の合成波は，表面が あらい繊維の表面の多数の表面要素での反射を経た電 場の合成波に比べて，より明りょうな干渉を経たもの であるので, 後者がさらに第 1 項の電場と干渉して強 め合いあるいは弱め合う可能性は前者の場合に比べて 低い. したがって，理想的な円柱について成立した上 記の強度についての加算性が, 表面があらい繊維につ いても成立するのは自然である。

\section{6. 結言}

本研究では，表面に自己相似的な微視構造がある緎 維の三次元幾何モデル化の方法を提案し，その繊維の ふく射散乱特性を調べた。得られた結果を以下にまと める :

（1）繊維のサイズパラメータが $P \leqq 100$ の程度で
ある場合, 瀻維表面の構造は繊維の散乱特性に影響を 与えない. 繊維が $P \geqq 300$ 程度に太くなり, それに伴 つて繊維表面のあらさが増すと, 散乱は‘粒子散乱的’ から“表面散乱的’に推移する。

（2）繊維の直径がふく射の波長に比べて大きい場 合, 表面が滑らかな繊維は, 繊維の軸に垂直な散乱面 の方向のみにふく射を強く散乱する。一方, 表面があ らい繊維はその方向に比較的弱く散乱し, 加えて, 散 乱面以外の方向には表面が滑らかな繊維の場合に比べ て強くふく射を散乱する。

（3）以上の特性は次の原因による，表面が滑らか な繊維では, 繊維の軸方向に並ぶ表面要素列からの位 相の揃った回折波が散乱面の方向でたがいに強め合う 干涉を生むが, 表面があらい繊維では, 散乱面以外の 方向でも強め合う干渉を生むことが可能になる.

（4）工学系の実在の繊維によるふく射の散乱を細 い繊維から太い繊維までにわたって統一的に取扱う理 論を示した。

本研究経費の一部は, 文部省科学研究費補助金 [基 盤研究 (A)（1 )0855505］によった。また, 京都大学 の若林英信, 服部純也両氏からは貴重なご示唆・ご援 助を得た。ここに記して感謝する.

\section{文献}

(1) van de Hulst, H. C., Light Scattering by Small Particles, (1981), 297-328, Dover, New York.

(2) Siegel, R. and Howell, J. R., Radiation Heat Transfer, 2 nd ed., (1981), 577-592, Hemisphere.

（3）牧野俊郎・蔵田秀敏, 表面があらい薄板状粒子によるふ く射の散乱, 機論, 60-570, B (1994)，530-536.

（4）牧野俊郎・加賀邦彦, 三次元重权合わせ法によりモデル 化したあらい表面に扔けるふく射の散乱, 機論, 58-553, B (1992), 2827-2833.

(5) Oglilvy, J. A., Theory of Wave Scattering from Ran dom Rough Surface, (1991), 73-85, Adam Hilger, Bris tol.

(6) Ishimaru, A., Wave Propagation and Scattering in Random Media, (1978), 9-40, Academic, New York.

（7）山田純・黑崎晏夫，サイズパラメータが大きい条件下で の瀻維集合体のふく射伝ぱ, 機論, 59-566, B (1993)，31873194 . 